\title{
5-hydroxymethylcytosine represses the activity of enhancers in embryonic stem cells: a new epigenetic signature for gene regulation
}

\author{
Inchan Choi ${ }^{\dagger}$, Rinho Kim ${ }^{\dagger}$, Hee-Woong Lim, Klaus H Kaestner ${ }^{*}$ and Kyoung-Jae Won ${ }^{*}$
}

\begin{abstract}
Background: Recent mapping of 5-hydroxymethylcytosine $(5 \mathrm{hmC})$ provides a genome-wide view of the distribution of this important chromatin mark. However, the role of $5 \mathrm{hmC}$ in specific regulatory regions is not clear, especially at enhancers.

Results: We found a group of distal transcription factor binding sites highly enriched for 5-hdroxymethylcytosine $(5 \mathrm{hmC})$, but lacking any known activating histone marks and being depleted for nascent transcripts, suggesting a repressive role for $5 \mathrm{hmC}$ in mouse embryonic stem cells (mESCs). 5 -formylcytosine ( $5 \mathrm{fC}$ ), which is known to mark poised enhancers where $\mathrm{H} 3 \mathrm{~K} 4 \mathrm{me} 1$ is enriched, is also observed at these sites. Furthermore, the $5 \mathrm{hmC}$ levels were inversely correlated with RNA polymerase II (PoIII) occupancy in mESCs as well as in fully differentiated adipocytes. Interestingly, activating H3K4me1/2 histone marks were enriched at these sites when the associated genes become activated following lineage specification. These putative enhancers were shown to be functional in embryonic stem cells when unmethylated. Together, these data suggest that $5 \mathrm{hmC}$ suppresses the activity of this group of enhancers, which we termed "silenced enhancers".
\end{abstract}

Conclusions: Our findings indicate that $5 \mathrm{hmC}$ has a repressive role at specific proximal and distal regulatory regions in $\mathrm{mESCs}$, and suggest that $5 \mathrm{hmC}$ is a new epigenetic mark for silenced enhancers.

Keywords: 5hmC, GROseq, Polll, eRNA, mESC, Enhancer

\section{Background}

5-hydroxymethylcytosine $(5 \mathrm{hmC})$ is an epigenetic mark that arises from oxidation of 5-methylcytosine $(5 \mathrm{mC})$ by Ten-eleven translocation (Tet) enzymes $[1,2]$. The $5 \mathrm{hmC}$ mark has been studied in several cell types, such as mouse embryonic stem cells (mESCs) [2,3], neuronal cells [4-6] and adipocytes [7]. $5 \mathrm{hmC}$ is enriched at promoters marked bivalently by $\mathrm{H} 3 \mathrm{~K} 4 \mathrm{me} 3$ and $\mathrm{H} 3 \mathrm{~K} 27 \mathrm{me} 3$ in mESCs [8], but depleted at promoters in the brain [9]. $5 \mathrm{hmC}$ is also enriched at specific transcription factor binding sites (TFBSs) in human and mouse ESCs [1,9-14]. Specifically, in mESCs, $5 \mathrm{hmC}$ is depleted at Sox 2 and Oct4 binding sites, but enriched for Esrrb and Tcfcp211 occupancy [12].

\footnotetext{
* Correspondence: kaestner@mail.med.upenn.edu; wonk@mail.med.upenn.edu ${ }^{\dagger}$ Equal contributors

Department of Genetics, Institute for Diabetes, Obesity and Metabolism, University of Pennsylvania, 3400 Civic Center Blvd, 19104 Philadelphia, PA, USA
}

In human embryonic stem cells (hESCs), $5 \mathrm{hmC}$ is highly enriched at CTCF, Nanog, and Oct4 binding sites [11]. Another study in hESC observed that the $5 \mathrm{hmC}$ profile showed a bimodal distribution at Oct4, Sox2, TAF1 and p300 binding sites [9]. While these studies suggest a possible regulatory role for $5 \mathrm{hmC}$ at promoters and TFBSs, its function at these regulatory regions remains unclear.

Here, we report on a new repressive role for $5 \mathrm{hmC}$ at specific regulatory regions in $\mathrm{mESCs}$. We show that $5 \mathrm{hmC}$ negatively correlates with nascent transcripts, especially at TFBSs. Interestingly, we discovered that a group of distal TFBSs displays a new epigenetic signature; these sites are exclusively enriched for $5 \mathrm{hmC}$, depleted for activating histone modification marks (H3K4me1 and H3K27ac), and significantly reduced for nascent transcripts or enhancer RNAs (eRNAs). The expression of the genes close to these TFBSs was significantly lower than that of genes close to other classes of TFBSs. In addition, we found that a fraction of these TFBSs becomes enriched for activating 
histone marks (H3K4me1/2) in neural progenitor cells (NPCs) or endomesoderm cells. RNA polymerase II (PolII) chromatin interaction analysis with paired-end tagging (ChIA-PET) [15] showed that the target genes of these regulatory regions were indeed significantly upregulated in NPCs. Enhancer/luciferase reporter assays demonstrated that these regions function as in gene activation when $5 \mathrm{hmC}$ is removed for these sites. Together, our findings suggest that $5 \mathrm{hmC}$ is as a novel marker for transcriptional silent enhancers in mESCs for regulatory regions that are activated during development.

\section{Results}

A group of $5 \mathrm{hmC}$-enriched distal TFBSs is lacking activating histone marks and nascent RNA transcription

A recent survey had found $5 \mathrm{hmC}$ enriched at TFBSs in hESC [11], mouse neuronal cells, and adipocytes [7]. Therefore, we investigated $5 \mathrm{hmC}$ levels [13] at the binding sites of 13 key transcription factors (TFs) (Nanog, Oct4, STAT3, Smad1, Sox2, Zfx, c-Myc, n-Myc, Klf4, Esrrb, Tcfcp2l1, E2f1 and CTCF) in mESC [16]. We confirmed previous results $[11,12]$ that $5 \mathrm{hmC}$ was generally depleted at the core of the proximal (within $2 \mathrm{~kb}$ to transcription start sites (TSSs) ) TFBSs, but relatively high in the regions neighboring $( \pm 2 \mathrm{~kb})$ the core (Additional file 1: Figure S1A). We also confirmed that $5 \mathrm{hmC}$ is highly enriched at the core of distal binding sites of many TFs, such as Zfx and Esrrb (Additional file 1: Figure S1B) [11,12].

To further investigate the role of $5 \mathrm{hmC}$ in gene regulation in conjunction with other epigenetic marks, we performed an integrative analysis using $5 \mathrm{hmC}, 5 \mathrm{mC}$ [13], Tet1 [10], H3K4me1/2/3, H3K27me3, RNA polymerase (Pol) II occupancy [17] and nascent RNAs from global run-on sequencing (GROseq) [18] data. We found that $5 \mathrm{hmC}$ levels were inversely correlated with nascent RNA transcription and Pol II occupancy at proximal TFBSs (Figure 1). We confirmed the levels of $5 \mathrm{hmC}$ positively correlated with the levels of the repressive $\mathrm{H} 3 \mathrm{~K} 27 \mathrm{me} 3$ histone mark at proximal TFBSs $[8,12]$.

To study the epigenetic landscapes surrounding distal TFBSs, we applied the $\mathrm{K}$-means algorithm $(\mathrm{K}=10)$ and found clusters marked by various epigenetic modifications (Figure 1B). Clusters 1, 8 and 10 showed the properties of active promoters: H3K4me $2 / 3$ enrichment with relatively low levels of H3K4me1 and the presence of nascent RNA transcripts. These clusters thus likely represent the promoters of long intergenic non-coding RNAs [19] or unannotated promoters of protein-coding genes. Clusters 5 and 9 showed H3K4me1 and H3K27ac enrichment, indicating active enhancers. These clusters, as well as clusters $3,4,6$, and 7 , showed only a small amount of nascent transcripts or enhancer RNAs (eRNAs), which have been known to correlate with the gene transcription levels of adjacent genes $[20,21]$. The presence of eRNAs in these clusters suggest that the TFBS at these clusters have an activating role.

We were especially interested in cluster 2, which was enriched for $5 \mathrm{hmC}$, but was depleted of eRNAs. Strikingly, this cluster had no activating histone marks such as H3K4me1 or H3K27ac [22-24], even though TFs bind at these sites (Figure $1 \mathrm{~B}$ and Additional file 1: Figure S2). $5 \mathrm{mC}$ was depleted at the core of the TFBS, consistent with the previous observation in hESCs [25]. Compared with other clusters, cluster 2 was characterized by low levels of

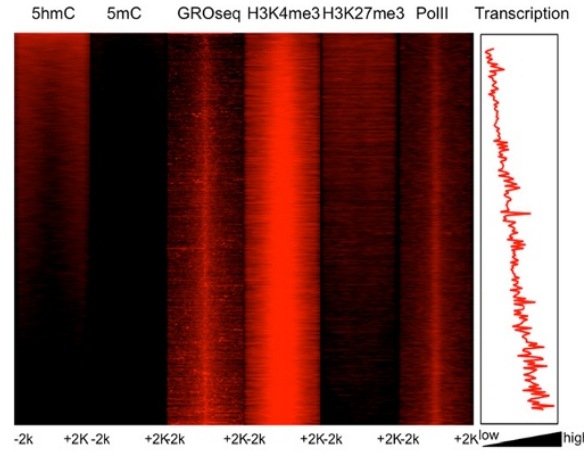

(A)

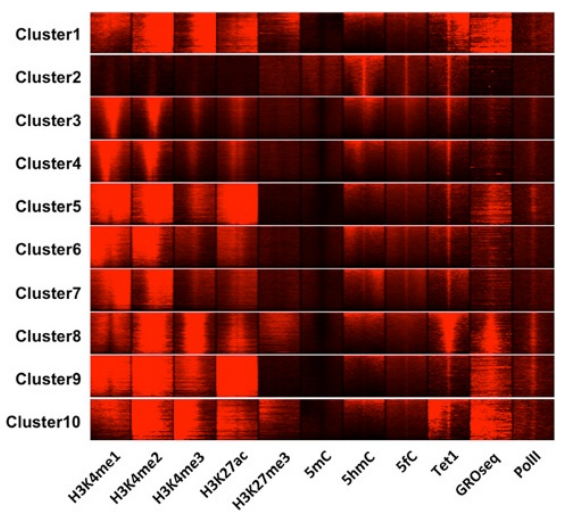

(B)

Figure $15 \mathrm{hmC}$ and other epigenetic modifications in ESCs. (A) Correlation between 5hmC and various marks. The TFBSs were sorted based on the $5 \mathrm{hmC}$ levels in $\pm 2 \mathrm{~K}$ regions relative to the center of the binding sites. $5 \mathrm{hmC}$ levels at promoter-proximal TFBSs were positively correlated with H327me3 levels and inversely correlated with GROseq and Polll levels. Transcription levels of the genes associated with the promoter were calculated using GROseq . In the sorted list, we averaged the transcription levels of the adjacent 100 genes. (B) Clustering results of $5 \mathrm{hmC}$ with other epigenomic data at distal (>2kbp from known TSSs) TFBSs. Cluster 1, 8 and 10 are enriched for H3K4me3 and GROseq, showing the properties of promoters. Cluster 5 and 9 display high levels of H3K27ac, indicative of active enhancers. Cluster 2 is enriched for $5 \mathrm{hmC}$ and $5 \mathrm{fC}$, has very low GROseq levels, and lacks all investigated histone marks. 
eRNAs and low PolII occupancy. To confirm the enrichment for $5 \mathrm{hmC}$, we investigated the profile of sequencing data from other independent studies $[1,12-14,26,27]$. Cluster 2 was enriched for $5 \mathrm{hmC}$ consistently for all four independently measured datasets (Additional file 1: Figure S3). We also examined TAB-seq, which provides baseresolution sequencing of $5 \mathrm{hmC}$ in $\mathrm{mESC}$ [3]. The TABseq profile also confirmed enrichment for $5 \mathrm{hmC}$ at the core of TFBSs for cluster 2 regions for both strands (Additional file 1: Figure S4). Together, these data suggest that $5 \mathrm{hmC}$ combined with absence of $\mathrm{H} 3 \mathrm{~K} 4 \mathrm{me} 1$ at distal TFBSs marks inactive enhancers.

Surprisingly, cluster 2 is also highly enriched for 5 -formylcytosine $(5 \mathrm{fC})$ compared with other clusters (Figure 1B). Both $5 \mathrm{fC}$ and $5 \mathrm{hmC}$ are involved in the active demethylation pathway $[28,29]$. Previous genome-wide study using $5 \mathrm{fC}$ revealed that $5 \mathrm{fC}$ is enriched at enhancers, especially at poised enhancers marked by H3K4me1 without H3K27ac [30]. However, the properties of the cluster 2 regions are novel, as they lack the H3K4me1 mark. This strongly suggests that $5 \mathrm{hmC}$ as well as $5 \mathrm{fC}$ mark a novel type of "poised" or silenced enhancer at distal regulatory regions where active histone modification marks are absent.

Next, we interrogated the state of the $5 \mathrm{hmC}$ mark in other cell types. In hESCs, we also identified a cluster enriched for $5 \mathrm{hmC}$ [3] but depleted for both H3K4me1 and H3K27ac at distal DNaseI hypersensitive sites (DHSs) [31] (Additional file 1: Figure S5). As in mESCs, GROseq levels in hESCs [32] were significantly weaker in this cluster $(\mathrm{p}$-value $=1.7 \mathrm{e}-14)$. In mature adipocytes, we observed $5 \mathrm{hmC}$ [7] enriched at over $20 \%$ of PPAR $\gamma$ binding sites [33] (Additional file 1: Figure S6). Surprisingly, PolII occupancy [33] was depleted when $5 \mathrm{hmC}$ was enriched (Additional file 1: Figure S6). These data indicate that $5 \mathrm{hmC}$ can be a repressive mark at distal regulatory regions regardless of cell type or differentiation state.

Additional file 1: Table S1 lists the number of binding sites for each TF in cluster 2 in $\mathrm{mESC}$. The majority of the cluster 2 regions were bound by CTCF, Tcfcp 211 or Esrrb. Fewer binding sites for Oct4, Sox2, and Nanog, the master regulators for self-renewal and pluripotency in ESCs, were observed in cluster 2 [34]. This is consistent with the observation that $5 \mathrm{hmC}$ is depleted at highly active enhancers in ESCs. We further investigated if ChIP intensity is lower for the TFBSs in cluster 2. We did not find statistical differences, even though the average profiles of the TFBSs in cluster 2 were slightly lower compared with the TFBSs in other clusters (Additional file 1: Figure S7).

\section{5hmC-enriched distal TFBSs are associated with developmental genes}

Next, we analyzed the correlation between $5 \mathrm{hmC}$ levels and transcriptional activity of the genes closest to the
TFBSs for each cluster. To calculate gene transcription levels, we calculated the reads per kilobase per million mapped reads (RPKM) from GROseq (see Methods). The genes mapping to the TFBSs in cluster 2 had strikingly reduced transcription levels compared to the genes in all other clusters ( $\mathrm{p}$-value $<1.3 \mathrm{e}-20$ ), even compared to clusters 8 and 10, where the repressive H3K27me3 mark was relatively enriched (Figure 1B).

$\mathrm{GO}$ analysis of the genes closest to the TFBSs in cluster 2 using GREAT [35] revealed that the genes in this cluster were enriched for developmental functions, such as "muscle cell development" ( $\mathrm{p}$-value $=3.4 \mathrm{e}-14)$ " and "foregut morphogenesis" (p-value $=5.8 \mathrm{e}-9) \quad($ Figure 2D). This is consistent with the fact that these genes are silent in ESCs and are only activated once differentiation commences.

A snapshot in Figure 3 shows the enrichment for $5 \mathrm{hmC}$ at the Klf4 and the Esrrb binding sites located in the first intron of Sorcs2. Sorcs2 is highly expressed in the developing and mature murine central nervous system [36]. We observed that Sorcs2 is silent in $\mathrm{mESC}$, and its promoter is bivalently marked by $\mathrm{H} 3 \mathrm{~K} 4 \mathrm{me} 3$ and H3K27me3 [17]. In mouse neural progenitor cells (NPCs), however, Sorcs2 is highly expressed [17]. The Klf4 and the Esrrb binding sites are marked by H3K4me1 in NPCs, suggesting an active role of this region as an enhancer during neural development.

\section{5hmC-enriched distal TFBSs become activated during development in a lineage-specific way}

Because of the coordination of high $5 \mathrm{hmC}$ levels with low expression of genes in cluster 2, we hypothesized that $5 \mathrm{hmC}$ may attenuate enhancer activity in $\mathrm{mESCs}$, which becomes activated later during development. Therefore, we analyzed H3K4me1/2 data in NPCs [17] and endomesoderm cells [37]. H3K4me1 and H3K4me2 are known to mark enhancers [22]. While H3K4me1/2 enhancer marks were depleted in mESCs, around $9 \%$ of distal TFBSs (out of 5,278 TFBSs) showed enriched H3K4me1/2 occupancy in NPCs, and an additional $20 \%$ of TFBSs were enriched for H3K4me1/2 in endomesoderm cells (Figure 4A). Overall, $5 \mathrm{hmC}$ levels were significantly decreased in cluster 2 regions after differentiation into NPCs [27]. This suggests that a group of $5 \mathrm{hmC}$-enriched enhancers are repressed in mESCs, but selectively become activated during development towards the neuronal or endomesoderm lineage. This implies that other regions in cluster 2 might be activated when ESCs are differentiated into other lineages such as primordial germ cells.

To further determine if the TFBSs in cluster 2 have activating roles in a lineage-specific way, we used chromatin connectivity maps from chromatin interaction analysis with paired-end tagging (ChIA-PET) associated with PolII in ESCs and NPCs [15]. By using the chromatin interaction 


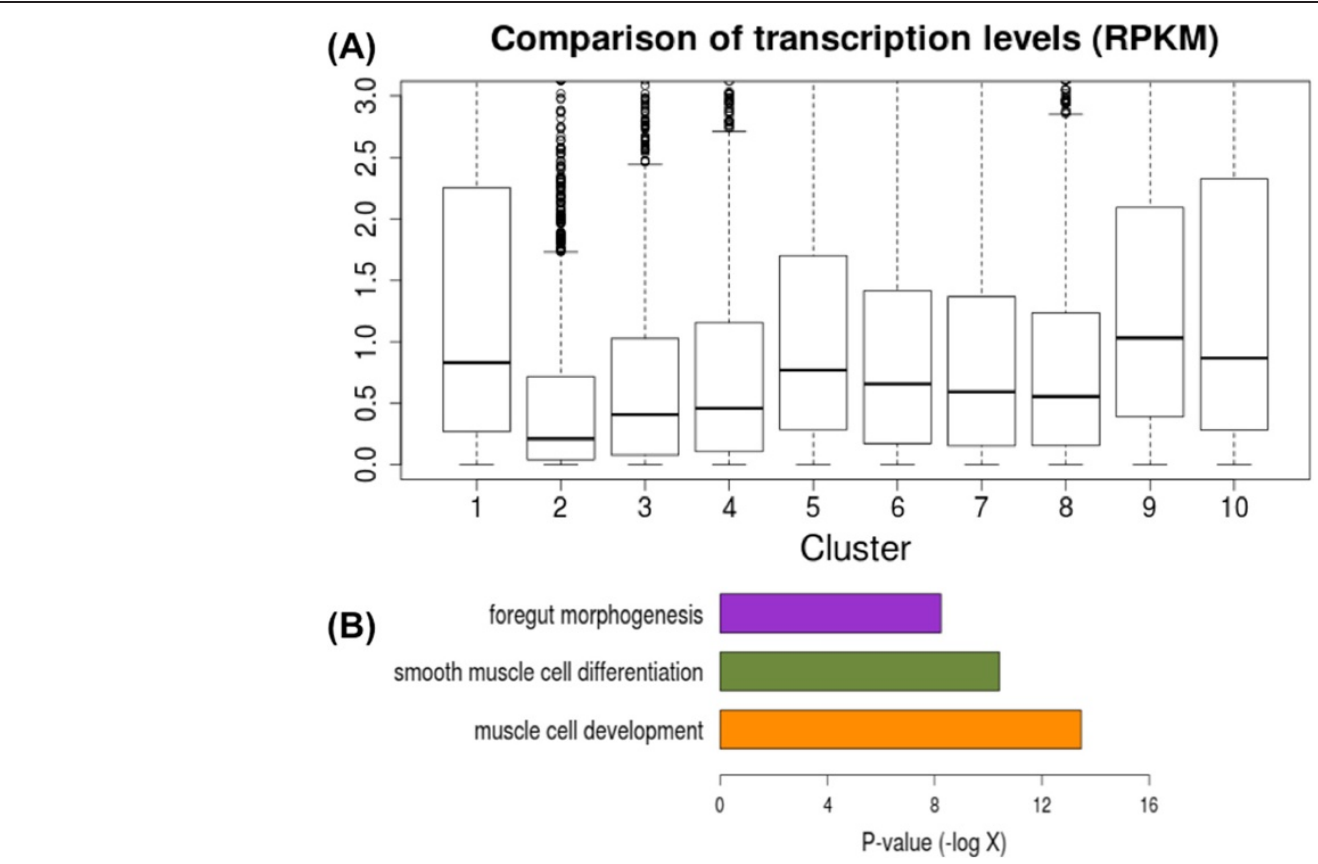

Figure 2 Functional analysis for TFBSs with $\mathbf{5 h m C}$. (A) Comparison of the transcription levels of the nearest genes between cluster 2 and the other 9 clusters of distal TFBSs identified in Figure 1B. The transcription levels (RPKM) were calculated using GROseq data. (B) GO analysis for the genes close to TFBSs in cluster 2. Organ development terms are enriched.

information, we mapped the target genes of the TFBSs in cluster 2 that were only selectively activated in NPCs. The target genes in ESCs were slightly downregulated in NPC (as well as in mouse embryo fibroblasts (MEFs)) because only a small portion of them become activated in a lineagespecific manner as shown in Figure 4A. In contrast, the target genes in NPCs become significantly upregulated during the transition from ESCs to NPCs (p-value <0.05). Moreover, the changes were significant compared with the target genes for clusters (all p-values were $<0.02$ ) (Additional file 1 : Figure S9). This further supports the notion that TFBSs in cluster 2 become activated in a lineage specific way following embryonic stem cell differentiation.

\section{Cluster 2 regions show enhancer activity in mESCs when devoid of $5 \mathrm{hmC}$}

Next, we directly determined if lack of $5 \mathrm{hmC}$ activates enhancer activity of the distal TFBSs in mESCs. We

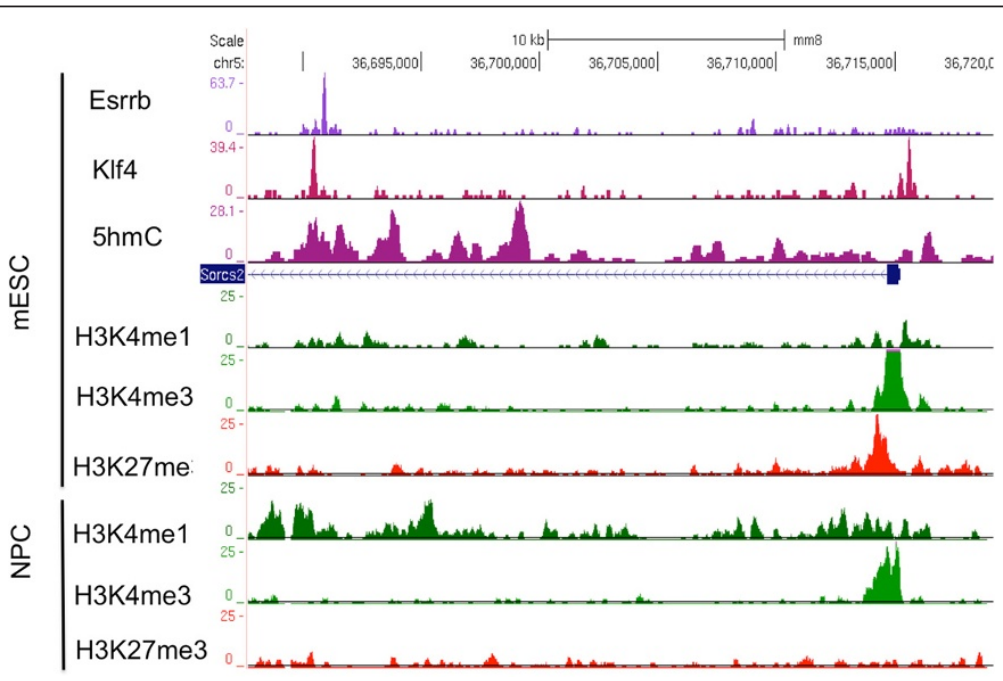

Figure 3 Chromatin organization at the Sorcs 2 gene in mESCs. The Klf4 and the Esrrb binding sites in the intron of Sorcs 2 gene are enriched for $5 \mathrm{hmC}$. These binding sites are depleted with H3K4me1 in mESCs, but are enriched in NPCs. 
(A)

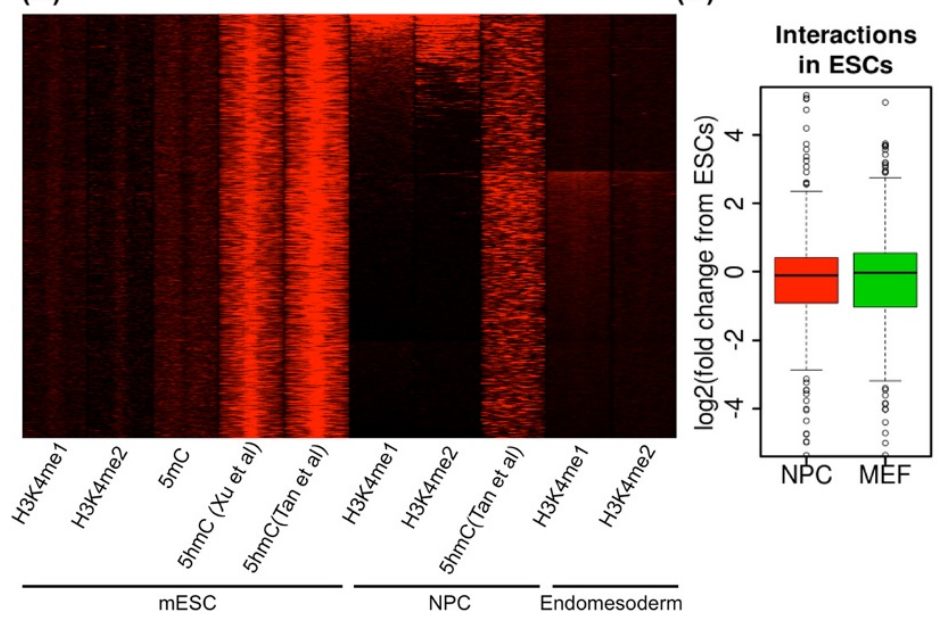

(B)

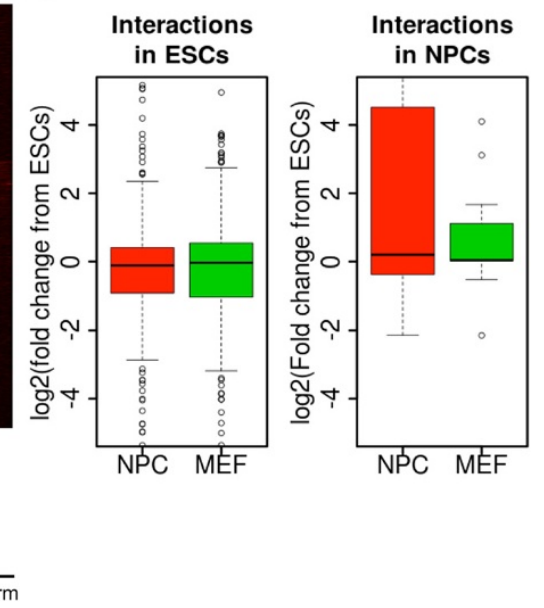

Figure 4 Lineage specific activation of distal TFBSs in cluster 2. (A) The enriched H3K4me1/2 in NPCs or endomesoderm cells suggests the potential lineage specific enhancer activation of the TFBSs in cluster 2 after differentiation. (B) The target genes of cluster 2 in NPCs identified using ChIA-PET become significantly upregulated ( $p$-value:0.04) when they gained interactions. The expression change in MEF is compared as a control ( $p$-value:0.12).

selected five highly 5-hydroxymethylated distal TFBSs regions from cluster 2, including the site in Sorcs2 (TFBS1). This site is also enriched for ChIA-PET [15] reads. We amplified these sequences ( $\pm 600 \mathrm{bp}$ ) by PCR and subcloned them into luciferase reporter plasmids containing a minimal promoter. We found that these DNA sequences indeed possess enhancer activity in mESCs when lacking $5 \mathrm{hmC}$, showing on average 3-fold increased luciferase activity compared to control (Figure 5). This in vitro study suggests that 5hmC-enriched distal TFBSs are bona fide enhancers, which are silent in $\mathrm{mESCs}$ when marked with $5 \mathrm{hmC}$.

We also investigated if $5 \mathrm{hmC}$ at distal regulatory regions has a repressive role using the Tet1 shRNA suppression experiments in mESCs [38]. We found that the target genes of cluster 2 were significantly upregulated (p-value $<0.01$ ) after Tet1 gene suppression, suggestive of repressive roles of $5 \mathrm{hmC}$ (Additional file 1: Figure S9). We did not find a similar pattern in Tet 2 shRNA-treated mESCs,

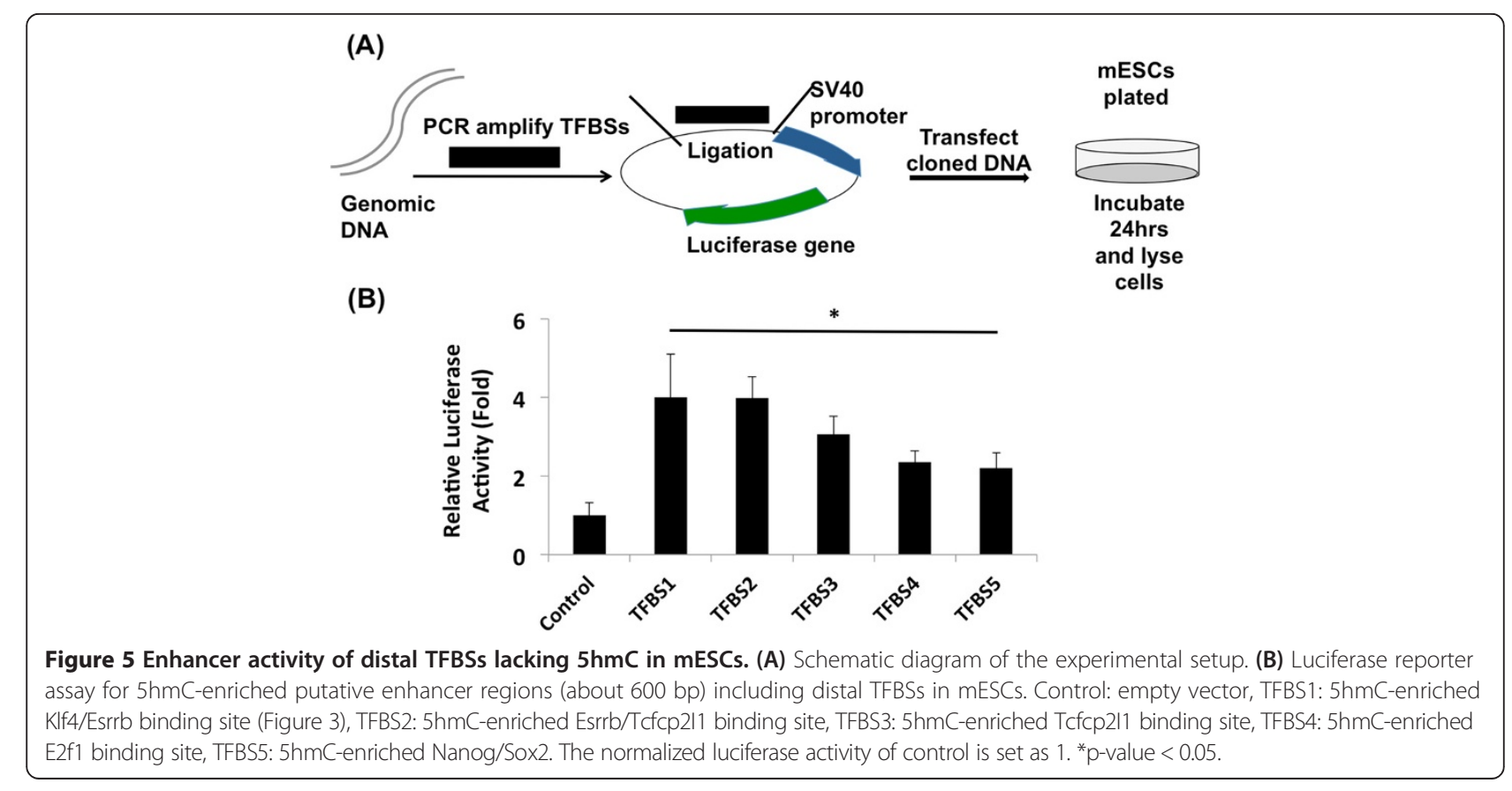


possibly due to the fact that Tet2 is dominantly associated with the $5 \mathrm{hmC}$ present in gene bodies [38].

\section{Discussion}

The field of DNA methylation has expanded recently, with the identification of multiple cytosine variants; $5 \mathrm{hmC}$, $5 \mathrm{fC}$, and 5-carboxylcytosine (5-caC) [28,39]. Among the cytosine variants, $5 \mathrm{hmC}$ has been most extensively studies [1,3,9-14]. Although there are genome-wide $5 \mathrm{hmC}$ maps in several cell types, our understanding about the functional role of $5 \mathrm{hmC}$ remains limited.

The contribution of the $5 \mathrm{hmC}$ modification to gene regulation is actively debated. Recent studies found that $5 \mathrm{hmC}$ gain is accompanied by H3K27me3 loss at promoters and in the gene body during neurogenesis, suggesting an activating role of $5 \mathrm{hmC}$ [40]. On the other hand, the presence of $5 \mathrm{hmC}$ at the promoter of bivalently marked genes $[8,12,14]$ and in vitro transcription studies revealed a repressive role of $5 \mathrm{hmC}$ at promoter regions [41]. However, the role of $5 \mathrm{hmC}$ at enhancers has not been investigated thus far.

We observed that enrichment of $5 \mathrm{hmC}$ corresponds with the depletion of eRNAs at distal TFBSs. Considering that eRNAs correlate with gene transcription [20,21], we suggest that low levels of $5 \mathrm{hmC}$ at enhancers are required for gene expression. Importantly, we found that a subset of distal TFBSs that carry the $5 \mathrm{hmC}$ mark in embryonic stem cells become enriched for the activating histone mark (H3K4me1/2) following differentiation into neural progenitors or endomesoderm, suggesting that distal TFBSs with $5 \mathrm{hmC}$ are repressed in $\mathrm{mESC}$ but become active enhancers in a lineage-specific manner. Indeed, using ChIA-PET interaction information [15], we found that those regions that gained connections to their target genes were significantly upregulated during differentiation compared with the target genes in other clusters. This suggests that their target genes were repressed in ESCs and become selectively activated in a lineagespecific way.

To ascertain if the proposed "silent enhancers" identified above can indeed function as enhancers we employed luciferase reporter assays. We demonstrated that the novel distal elements, characterized by TF binding, high levels of $5 \mathrm{hmC}$, and absence of the H3K4me1 "enhancer" mark, can indeed function as enhancers in mESCs if they are devoid of the $5 \mathrm{hmC}$ modification. This experiment is consistent with the notion that $5 \mathrm{hmC}$ could inhibit enhancer activity at a subset of distal TFBSs in mESCs.

Our findings are different from the work of Sérandour and colleagues [7], who had suggested an activating role for $5 \mathrm{hmC}$ at distal regulatory regions. They identified $5 \mathrm{hmC}$ peaks after differentiation which were surrounded by the activating H3K4me2 mark. However, more than $50 \%$ the $5 \mathrm{hmC}$ peaks they identified were located at genic regions, where they are known to be associated with gene activation $[10,12,38,40,42]$. It is also possible that the $5 \mathrm{hmC}$ peaks at distal regions are associated with noncoding RNAs such as long non-coding RNAs (lincRNAs) [43]. Sérandour and colleagues also identified $5 \mathrm{hmC}$ at distal PPARy binding sites [33]. Even though Sérandour and colleagues proposed an activating role of $5 \mathrm{hmC}$ at these master regulator in adipocytes, only a portion of $\mathrm{PPAR} \gamma$ binding sites were enriched for $5 \mathrm{hmC}$ [7]. We revisited their data and found that $5 \mathrm{hmC}$ was only present at sited lacking PolII occupancy (Additional file 1: Figure S6), indicating that $5 \mathrm{hmC}$ at PPAR $\gamma$ binding sites bears repressive roles in mature adipocytes.

In hESCs, we also identified a group of distal DHSs with strong $5 \mathrm{hmC}$ but weak H3K4me1 and H3K27ac (Additional file 1: Figure S5). The GROseq levels were significantly weak for the group with $5 \mathrm{hmC}$ (Additional file 1 : Figure S5). These lines of evidences suggest a general repressive role of $5 \mathrm{hmC}$ at distal regulatory regions.

In ESCs, poised enhancers have been suggested to exist at sites where both activating marks (H3K4me1) and repressive marks (H3K27me3) are enriched, but H3K27ac is depleted $[23,24]$. $5 \mathrm{fC}$ is enriched in this type of poised enhancers $(\mathrm{H} 3 \mathrm{~K} 4 \mathrm{me} 1[+]$ and $\mathrm{H} 3 \mathrm{~K} 27 \mathrm{ac}[-])$ [30]. In contrast to these poised enhancers, we identify a novel group of enhancers with no activating histone marks (H3K4me1[-] and H3K27ac[-]) but enrichment only for 5hmC. Furthermore, this group is strongly enriched for $5 \mathrm{fC}$, even though cluster 2 lacks the H3K4me1 mark (Figure 1). Our results strongly suggest that $5 \mathrm{hmC}$ and $5 \mathrm{fC}$ can be epigenetic mark for poised or silent enhancers. As shown in our results, many of these enhancers display activating histone marks only after differentiation has occurred (Figure 4). The existence of $5 \mathrm{hmC}$ and $5 \mathrm{fC}$ also show the active oxidation dynamics at these sites.

We found that $5 \mathrm{hmC}$ was enriched at distal PPAR $\gamma$ binding sites in fully differentiated adipocytes. These findings suggest $5 \mathrm{hmC}$ as a new marker for poised enhancers even in absence of H3K4me1 and H3K27me3. Additionally, we also found enriched $5 \mathrm{hmC}$ in NPC at the subset of the active TFBSs (except for cluster 2) in mESCs (Additional file 1: Figure S10). This may suggest that active enhancers in mESCs are repressed by $5 \mathrm{hmC}$ in NPC to remove the enhancer activities in MESCs.

The majority of cluster 2 regions are CTCF binding sites (Additional file 1: Table S2). In general, $5 \mathrm{hmC}$ levels negatively correlated with CTCF occupancy in cluster 2 (Additional file 1: Figure S11). After differentiation into NPCs, $5 \mathrm{hmC}$ became depleted at these sites even though the binding CTCF remained. At these sites, we did not observe activating H3K4me1 and H3K4me2 marks. However, it is difficult to discuss the role of $5 \mathrm{hmCs}$ at these sites, because CTCF takes part in various regulatory roles including transcriptional activation, repression, as well as 
the formation of higher order chromatin structure [44]. The function of $5 \mathrm{hmC}$ in $\mathrm{mESCs}$ at CTCF binding sites warrants further study.

\section{Conclusions}

We report a new repressive role for $5 \mathrm{hmC}$ in gene regulatory regions in mESCs. The TFBSs enriched for $5 \mathrm{hmCs}$ were depleted for nascent transcripts and activating histone modification marks in human and mouse ESCs. Furthermore, the $5 \mathrm{hmC}$ levels were inversely correlated with PolII occupancy in $\mathrm{mESCs}$ as well as in fully differentiated adipocytes. Our findings indicate that $5 \mathrm{hmC}$ has a repressive role at specific distal regulatory regions and suggest that $5 \mathrm{hmC}$ is a new epigenetic mark for silenced enhancers.

\section{Methods}

\section{Experimental crocedures}

We used genome-wide GROseq maps [18] and ChIP-seq data for chromatin status [17,45], PolII occupancy [17], $5 \mathrm{mC}[10]$, and Tet1 occupancy [10] in mESCs for our integrated analysis. We employed H3K4me1/2 data from NPC [17] and endomesoderm cells [37] to analyze the fate of our novel $5 \mathrm{hmC}$ regions after differentiation. We also included $5 \mathrm{hmC}$ from various independent studies $[1,12-14,26,27]$ for our analysis. Additional file 1: Table S1 summarizes all genome-wide datasets we used in our study.

All ChIP-seq data were normalized to 10 reads per kilobase per million mapped reads (RPKM) [46]. For clustering analysis we used Mev V4.8 [47] and applied the K-means clustering algorithm using the Pearson correlation with absolute distance as a metric. To cluster distal TFBs in mESCs, we used the H3K4me1/2/3, H3K27ac, H3K27me and $5 \mathrm{hmC}$ levels and generated applied clustering $(\mathrm{K}=10)$. We showed other epigenetic marks and GROseq and PolII next to the identified clusters.

To study the functional roles of $5 \mathrm{hmC}$ in various regulatory regions, we employed binding site data of $13 \mathrm{TFs}$ (Nanog, Oct4, STAT3, Smad1, Sox2, Zfx, c-Myc, n-Myc, Klf4, Esrrb, Tcfcp2l1, E2f1 and CTCF) in mESC [16].

To investigate $5 \mathrm{hmC}$ and nascent RNA levels across genes, we divided the genes into promoter (from $-1 \mathrm{Kbp}$ to 500 bp around the annotated start site), 3 ' end (from -500 bp to $500 \mathrm{bp}$ around the annotated termination site), and gene body regions (500 bp from the annotated start site to $-500 \mathrm{bp}$ from the annotated termination site). For transcription levels, we calculated RPKM using GROseq reads from $500 \mathrm{bp}$ of the annotated start site to the annotated termination site in order not to include transcriptional pausing at promoters $[20,48]$.

\section{Luciferase reporter assay}

Genomic DNA was prepared from R1 mouse embryonic stem cells [49]. About $600 \mathrm{bp}$ genomic fragments for five distal TFBSs in cluster 2 were amplified by PCR with
dNTPs and the PCR products ligated into the pGL3-SV40 luciferase vector (Promega). Empty vector (control) or cloned vectors were transfected directly into $\mathrm{R} 1 \mathrm{mESC}$, together with the pRL-tk vector (Promega) as internal control, using Lipofectamine LTX (Life Technologies). At $24 \mathrm{~h}$ after transfection, cells were harvested and lysates subjected to the dual-luciferase reporter assay (Promega). Firefly luciferase activity was measured and normalized to the internal control, Renilla luciferase activity.

\section{Additional file}

Additional file 1: Figure S1. $5 \mathrm{hmC}$ profile at promoters and enhancers. Figure S2. Comparison of the characteristics of each cluster. Figure S3. Comparison of the $5 \mathrm{hmC}$ patterns for each cluster. Figure S4. The $5 \mathrm{hmC}$ profile of cluster 2 using TAB-Seq. Figure S5. The $5 \mathrm{hmC}$ clusters in hESCs. Figure S6. The $5 \mathrm{hmC}$ clusters in mature adipocytes [10]. Figure S7.2 The average profiles of TFs at cluster 2. Figure S8. The gene expression change for the target genes for each cluster. Figure S9. The gene expression changes of the target genes after Tet1 knockdown for each cluster. Figure S10. The $5 \mathrm{hmC}$ in mESC and NPC at the TFBSs in mESCs. Figure S11. $5 \mathrm{hmC}$ at CTCF binding sites in cluster 2. Table S1. Datasets. Table S2. The frequency of transcription factor occupancy in cluster 2.

\section{Competing interest}

The authors declared that they have no competing interest.

\section{Authors' contribution}

KHK and KJW conceived of the study, participated in its design and coordination and helped to draft the manuscript. IC and HWL performed bioinformatics analysis. RK carried out the luciferase reporter assay. All authors read and approved the final manuscript.

\section{Acknowledgments}

This work was supported by National Institutes of Health grant R21DK098769-01 and a pilot award from the DRC at the University of Pennsylvania from a grant sponsored by NIH DK 19525 to K.-J.W. We thank the University of Pennsylvania Diabetes Research Center (DRC) for the use of the Functional Genomics Core Core (P30-DK19525).

Received: 19 May 2014 Accepted: 31 July 2014

Published: 9 August 2014

\section{References}

1. Williams K, Christensen J, Pedersen MT, Johansen JV, Cloos PA, Rappsilber J, Helin K: TET1 and hydroxymethylcytosine in transcription and DNA methylation fidelity. Nature 2011, 473(7347):343-348.

2. Tahiliani M, Koh KP, Shen Y, Pastor WA, Bandukwala H, Brudno Y, Agarwal S, lyer LM, Liu DR, Aravind L, Rao A: Conversion of 5-methylcytosine to 5-hydroxymethylcytosine in mammalian DNA by MLL partner TET1. Science 2009, 324(5929):930-935.

3. Yu M, Hon GC, Szulwach KE, Song CX, Zhang L, Kim A, Li X, Dai Q, Shen Y, Park B, Min JH, Jin P, Ren B, He C: Base-resolution analysis of 5-hydroxymethylcytosine in the Mammalian genome. Cell 2012, 149(6):1368-1380.

4. Kriaucionis $\mathrm{S}$, Heintz N: The nuclear DNA base 5-hydroxymethylcytosine is present in Purkinje neurons and the brain. Science 2009, 324(5929):929-930.

5. Song CX, Szulwach KE, Fu Y, Dai Q, Yi C, Li X, Li Y, Chen CH, Zhang W, Jian X, Wang J, Zhang L, Looney TJ, Zhang B, Godley LA, Hicks LM, Lahn BT, Jin $P, H e C$ : Selective chemical labeling reveals the genome-wide distribution of 5-hydroxymethylcytosine. Nat Biotechnol 2011, 29(1):68-72.

6. Mellen M, Ayata P, Dewell S, Kriaucionis S, Heintz N: MeCP2 Binds to 5hmC Enriched within Active Genes and Accessible Chromatin in the Nervous System. Cell 2012, 151(7):1417-1430.

7. Serandour AA, Avner S, Oger F, Bizot M, Percevault F, Lucchetti-Miganeh C, Palierne G, Gheeraert C, Barloy-Hubler F, Peron CL, Madigou T, Durand E, 
Froguel P, Staels B, Lefebvre P, Métivier R, Eeckhoute J, Salbert G: Dynamic hydroxymethylation of deoxyribonucleic acid marks differentiation-associated enhancers. Nucleic Acids Res 2012, 40(17):8255-8265.

8. Matarese F: Carrillo-de Santa Pau E, Stunnenberg HG: 5Hydroxymethylcytosine: a new kid on the epigenetic block? Mol Syst Biol 2011, 7:562.

9. Szulwach KE, Li X, Li Y, Song CX, Han JW, Kim S, Namburi S, Hermetz K, Kim J J, Rudd MK, Yoon YS, Ren B, He C, Jin P: Integrating 5-hydroxymethylcytosine into the epigenomic landscape of human embryonic stem cells. PLoS Genet 2011, 7(6):e1002154.

10. Ficz G, Branco MR, Seisenberger S, Santos F, Krueger F, Hore TA, Marques CJ, Andrews S, Reik W: Dynamic regulation of 5-hydroxymethylcytosine in mouse ES cells and during differentiation. Nature 2011, 473(7347):398-402.

11. Stroud H, Feng S, Morey Kinney S, Pradhan S, Jacobsen SE: 5Hydroxymethylcytosine is associated with enhancers and gene bodies in human embryonic stem cells. Genome Biol 2011, 12(6):R54

12. Wu H, D'Alessio AC, Ito S, Wang Z, Cui K, Zhao K, Sun YE, Zhang Y: Genome-wide analysis of 5-hydroxymethylcytosine distribution reveals its dual function in transcriptional regulation in mouse embryonic stem cells. Genes Dev 2011, 25(7):679-684.

13. $X u Y$, Wu F, Tan $L$, Kong $L$, Xiong $L$, Deng J, Barbera AJ, Zheng $L$, Zhang $H$, Huang S, Min J, Nicholson T, Chen T, Xu G, Shi Y, Zhang K, Shi YG: Genome-wide regulation of $5 \mathrm{hmC}, 5 \mathrm{mC}$, and gene expression by Tet1 hydroxylase in mouse embryonic stem cells. Mol Cell 2011, 42(4):451-464.

14. Pastor WA, Pape UJ, Huang $Y$, Henderson HR, Lister R, Ko M, McLoughlin EM, Brudno Y, Mahapatra S, Kapranov P, Tahiliani M, Daley GQ, Liu XS, Ecker JR, Milos PM, Agarwal S, Rao A: Genome-wide mapping of 5-hydroxymethylcytosine in embryonic stem cells. Nature 2011, 473(7347):394-397.

15. Zhang Y, Wong CH, Birnbaum RY, Li G, Favaro R, Ngan CY, Lim J, Tai E, Poh HM, Wong E, Mulawadi FH, Sung WK, Nicolis S, Ahituv N, Ruan Y, Wei CL: Chromatin connectivity maps reveal dynamic promoter-enhancer long-range associations. Nature 2013, 504(7479):306-310.

16. Chen $X, X u H$, Yuan $P$, Fang F, Huss M, Vega VB, Wong E, Orlov YL, Zhang W, Jiang J, Loh YH, Yeo HC, Yeo ZX, Narang V, Govindarajan KR, Leong B, Shahab A, Ruan Y, Bourque G, Sung WK, Clarke ND, Wei CL, Ng HH: Integration of external signaling pathways with the core transcriptional network in embryonic stem cells. Cell 2008, 133(6):1106-1117.

17. Mikkelsen TS, Ku M, Jaffe DB, Issac B, Lieberman E, Giannoukos G, Alvarez P, Brockman W, Kim TK, Koche RP, Lee W, Mendenhall E, O'Donovan A, Presser A, Russ C, Xie X, Meissner A, Wernig M, Jaenisch R, Nusbaum C, Lander ES, Bernstein BE: Genome-wide maps of chromatin state in pluripotent and lineage-committed cells. Nature 2007, 448(7153):553-560.

18. Min IM, Waterfall JJ, Core LJ, Munroe RJ, Schimenti J, Lis JT: Regulating RNA polymerase pausing and transcription elongation in embryonic stem cells. Genes Dev 2011, 25(7):742-754.

19. Guttman M, Amit I, Garber M, French C, Lin MF, Feldser D, Huarte M, Zuk O, Carey BW, Cassady JP, Cabili MN, Jaenisch R, Mikkelsen TS, Jacks T, Hacohen N, Bernstein BE, Kellis M, Regev A, Rinn JL, Lander ES: Chromatin signature reveals over a thousand highly conserved large non-coding RNAs in mammals. Nature 2009, 458(7235):223-227.

20. Core LJ, Waterfall JJ, Lis JT: Nascent RNA sequencing reveals widespread pausing and divergent initiation at human promoters. Science 2008, 322(5909):1845-1848.

21. Wang D, Garcia-Bassets I, Benner C, Li W, Su X, Zhou Y, Qiu J, Liu W, Kaikkonen MU, Ohgi KA, Glass CK, Rosenfeld MG, Fu XD: Reprogramming transcription by distinct classes of enhancers functionally defined by eRNA. Nature 2011 474(7351):390-394

22. Heintzman ND, Stuart RK, Hon G, Fu Y, Ching CW, Hawkins RD, Barrera LO, Van Calcar S, Qu C, Ching KA, Wang W, Weng Z, Green RD, Crawford GE, Ren $B$ : Distinct and predictive chromatin signatures of transcriptional promoters and enhancers in the human genome. Nat Genet 2007, 39(3):311-318.

23. Rada-Iglesias A, Bajpai R, Swigut T, Brugmann SA, Flynn RA, Wysocka J: A unique chromatin signature uncovers early developmental enhancers in humans. Nature 2011, 470(7333):279-283.

24. Creyghton MP, Cheng AW, Welstead GG, Kooistra T, Carey BW, Steine EJ, Hanna J, Lodato MA, Frampton GM, Sharp PA, Boyer LA, Young RA, Jaenisch R: Histone H3K27ac separates active from poised enhancers and predicts developmental state. Proc Natl Acad Sci USA 2010, 107(50):21931-21936.
25. Lister R, Pelizzola M, Dowen RH, Hawkins RD, Hon G, Tonti-Filippini J, Nery JR, Lee L, Ye Z, Ngo QM, Edsall L, Antosiewicz-Bourget J, Stewart R, Ruotti V, Millar AH, Thomson JA, Ren B, Ecker JR: Human DNA methylomes at base resolution show widespread epigenomic differences. Nature 2009, 462(7271):315-322.

26. Wu H, Zhang Y: Tet1 and 5-hydroxymethylation: a genome-wide view in mouse embryonic stem cells. Cell Cycle 2011, 10(15):2428-2436.

27. Tan $L$, Xiong $L, X u$ W, Wu F, Huang N, Xu Y, Kong L, Zheng L, Schwartz L, Shi Y, Shi YG: Genome-wide comparison of DNA hydroxymethylation in mouse embryonic stem cells and neural progenitor cells by a new comparative hMeDIP-seq method. Nucleic Acids Res 2013, 41(7):e84.

28. Ito S, Shen L, Dai Q, Wu SC, Collins LB, Swenberg JA, He C, Zhang Y: Tet proteins can convert 5-methylcytosine to 5-formylcytosine and 5-carboxylcytosine. Science 2011, 333(6047):1300-1303.

29. Maiti A, Drohat AC: Thymine DNA glycosylase can rapidly excise 5-formylcytosine and 5-carboxylcytosine: potential implications for active demethylation of CpG sites. J Biol Chem 2011, 286(41):35334-35338.

30. Song CX, Szulwach KE, Dai Q, Fu Y, Mao SQ, Lin L, Street C, Li Y, Poidevin M, Wu H, Gao J, Liu P, Li L, Xu GL, Jin P, He C: Genome-wide profiling of 5-formylcytosine reveals its roles in epigenetic priming. Cell 2013, 153(3):678-691.

31. Bernstein BE, Stamatoyannopoulos JA, Costello JF, Ren B, Milosavljevic A, Meissner A, Kellis M, Marra MA, Beaudet AL, Ecker JR, Farnham PJ, Hirst M, Lander ES, Mikkelsen TS, Thomson JA: The NIH Roadmap Epigenomics Mapping Consortium. Nat Biotechnol 2010, 28(10):1045-1048.

32. Sigova AA, Mullen AC, Molinie B, Gupta S, Orlando DA, Guenther MG, Almada AE, Lin C, Sharp PA, Giallourakis CC, Young RA: Divergent transcription of long noncoding RNA/mRNA gene pairs in embryonic stem cells. Proc Natl Acad Sci USA 2013, 110(8):2876-2881.

33. Nielsen R, Pedersen TA, Hagenbeek D, Moulos P, Siersbaek R, Megens E, Denissov S, Borgesen M, Francoijs KJ, Mandrup S, Stunnenberg HG: Genome-wide profiling of PPARgamma:RXR and RNA polymerase II occupancy reveals temporal activation of distinct metabolic pathways and changes in RXR dimer composition during adipogenesis. Genes Dev 2008, 22(21):2953-2967.

34. Boyer LA, Lee TI, Cole MF, Johnstone SE, Levine SS, Zucker JP, Guenther MG, Kumar RM, Murray HL, Jenner RG, Gifford DK, Melton DA, Jaenisch R, Young RA: Core transcriptional regulatory circuitry in human embryonic stem cells. Cell 2005, 122(6):947-956.

35. McLean CY, Bristor D, Hiller M, Clarke SL, Schaar BT, Lowe CB, Wenger AM, Bejerano G: GREAT improves functional interpretation of cis-regulatory regions. Nat Biotechnol 2010, 28(5):495-501.

36. Rezgaoui M, Hermey G, Riedel IB, Hampe W, Schaller HC, Hermans-Borgmeyer I: Identification of SorCS2, a novel member of the VPS10 domain containing receptor family, prominently expressed in the developing mouse brain. Mech Dev 2001, 100(2):335-338.

37. Yu P, Xiao S, Xin X, Song CX, Huang W, McDee D, Tanaka T, Wang T, He C, Zhong S: Spatiotemporal clustering of the epigenome reveals rules of dynamic gene regulation. Genome Res 2013, 23(2):352-364.

38. Huang Y, Chavez L, Chang X, Wang X, Pastor WA, Kang J, Zepeda-Martinez JA, Pape UJ, Jacobsen SE, Peters B, Rao A: Distinct roles of the methylcytosine oxidases Tet 1 and Tet2 in mouse embryonic stem cells. Proc Natl Acad Sci USA 2014, 111(4):1361-1366.

39. He YF, Li BZ, Li Z, Liu P, Wang Y, Tang Q, Ding J, Jia Y, Chen Z, Li L, Sun Y, Li X, Dai Q, Song CX, Zhang K, He C, Xu GL: Tet-mediated formation of 5-carboxylcytosine and its excision by TDG in mammalian DNA. Science 2011, 333(6047):1303-1307.

40. Hahn MA, Qiu R, Wu X, Li AX, Zhang H, Wang J, Jui J, Jin SG, Jiang Y, Pfeifer GP, LU Q: Dynamics of 5-hydroxymethylcytosine and chromatin marks in Mammalian neurogenesis. Cell Rep 2013, 3(2):291-300.

41. Robertson J, Robertson AB, Klungland $A$ : The presence of 5-hydroxymethylcytosine at the gene promoter and not in the gene body negatively regulates gene expression. Biochem Biophys Res Commun 2011, 411(1):40-43.

42. Kim M, Park YK, Kang TW, Lee SH, Rhee YH, Park JL, Kim HJ, Lee D, Kim SY, Kim YS: Dynamic changes in DNA methylation and hydroxymethylation when hES cells undergo differentiation toward a neuronal lineage. Hum Mol Genet 2014, 23(3):657-667.

43. Guttman M, Garber M, Levin JZ, Donaghey J, Robinson J, Adiconis X, Fan L, Koziol MJ, Gnirke A, Nusbaum C, Rinn JL, Lander ES, Regev A: Ab initio reconstruction of cell type-specific transcriptomes in mouse reveals the 
conserved multi-exonic structure of lincRNAs. Nat Biotechnol 2010 28(5):503-510.

44. Nikolaev LG, Akopov SB, Didych DA, Sverdlov ED: Vertebrate Protein CTCF and its Multiple Roles in a Large-Scale Regulation of Genome Activity. Curr Genomics 2009, 10(5):294-302.

45. Meissner A, Mikkelsen TS, Gu H, Wernig M, Hanna J, Sivachenko A, Zhang X, Bernstein BE, Nusbaum C, Jaffe DB, Gnirke A, Jaenisch R, Lander ES: Genome-scale DNA methylation maps of pluripotent and differentiated cells. Nature 2008, 454(7205):766-770.

46. Mortazavi A, Williams BA, McCue K, Schaeffer L, Wold B: Mapping and quantifying mammalian transcriptomes by RNA-Seq. Nat Methods 2008, 5(7):621-628.

47. Saeed Al, Bhagabati NK, Braisted JC, Liang W, Sharov V, Howe EA, Li J, Thiagarajan M, White JA, Quackenbush J: TM4 microarray software suite. Methods Enzymol 2006, 411:134-193.

48. Rahl PB, Lin CY, Seila AC, Flynn RA, McCuine S, Burge CB, Sharp PA, Young RA: c-Myc regulates transcriptional pause release. Cell 2010, 141(3):432-445.

49. Nagy A, Rossant J, Nagy R, Abramow-Newerly W, Roder JC: Derivation of completely cell culture-derived mice from early-passage embryonic stem cells. Proc Natl Acad Sci USA 1993, 90(18):8424-8428.

doi:10.1186/1471-2164-15-670

Cite this article as: Choi et al.: 5-hydroxymethylcytosine represses the activity of enhancers in embryonic stem cells: a new epigenetic signature for gene regulation. BMC Genomics 2014 15:670.

\section{Submit your next manuscript to BioMed Central and take full advantage of:}

- Convenient online submission

- Thorough peer review

- No space constraints or color figure charges

- Immediate publication on acceptance

- Inclusion in PubMed, CAS, Scopus and Google Scholar

- Research which is freely available for redistribution 